\title{
Szívvédelem szervetlen nitrátokkal
}

\author{
Végh Ágnes, Demeter-Haludka Vivien, Kovács Mária, Miskolczi Gottfried
}

\author{
Szegedi Tudományegyetem, Farmakológiai és Farmakoterápiai Intézet, Szeged \\ Levelezési cím: Prof. dr. Végh Ágnes, Szegedi Tudományegyetem, Farmakológiai és Farmakoterápiai Intézet, \\ Szeged, Dóm tér 12. E-mail: vegh.agnes@med.u-szeged.hu
}

\begin{abstract}
A szerves nitriteket és nitrátokat több mint 100 éve alkalmazzák a koszorúér-betegség talaján kialakuló iszkémiás szívbetegségek és azok súlyos következményeinek kezelésére. Kutatócsoportunk számos kísérletes munka alapján igazolta, hogy a szerves nitritek és nitrátok, mint nitrogén-monoxid donorvegyületek, jelentős mértékben csökkentik a szívizom heveny iszkémiás és reperfúziós károsodása során kialakuló, gyakran fatális kimenetelü ritmuszavarokat. Bár az aritmiákkal szembeni védőhatás mechanizmusa nem pontosan ismert, feltételezhető, hogy a kardioprotektív hatásban a nitritekből és nitrátokból képződő nitrogén-monoxid biológiai hozzáférhetőségének iszkémia/reperfúzió alatti javulása és az ennek következtében aktiválódó, a nitrogén-monoxid széles körü biológiai aktivitásán keresztül érvényesülő, folyamatoknak meghatározó szerepe van.

Az elmúlt évtized egyik jelentős paradigma váltásának tekinthető az a felismerés, hogy a korábban hatástalan metabolikus végtermékként számon tartott szervetlen nitritek és nitrátok is önálló biológiai hatással rendelkeznek. Ezek a molekulák, amelyek a nitrogén-monoxid természetes oxidációs metabolizmusának termékei, reduktív környezetben (pl. hipoxia, iszkémia) könnyen nitrogén-monoxiddá redukálódnak, ezáltal biztosítva a nitrogén-monoxid hozzáférhetőségét olyan kóros körülmények fennállása esetén is, amikor a nitrogén-monoxid normális, enzimatikus úton történő szintézise károsodott. Ilyenformán, a szervetlen nitritek és nitrátok, mint nitrogén-monoxid raktárak funkcionálhatnak a szervezetben.

A Szegedi Tudományegyetem Farmakológiai és Farmakoterápiai Intézetének Hemodinamikai Kutatócsoportja évtizedek óta foglalkozik a nitrogén-monoxid kardioprotektív hatásának vizsgálatával. Ezen belül is elsődleges célunk a nitrogén-monoxidnak az akut iszkémia/reperfúzió során megjelenő súlyos kamrai ritmuszavarokra gyakorolt hatásának és az ebben szerepet játszó mechanizmusoknak a felderítése volt. Miután Papp Gyula professzor, akadémikus, intézetvezetőként részese és mentora volt ennek a kutatómunkának, 80. születésnapjára olyan összefoglalóval kívánjuk tiszteletünket leróni, amely az elmúlt 5 évben, a szervetlen nitritek, ezen belül is a nátrium-nitrit korai és késői antiaritmiás hatásának felderítésére végeztünk.
\end{abstract}

Kulcsszavak: aritmia, iszkémia/reperfúzió, szervetlen nitritek, nitrogén-monoxid, állatkísérlet

\section{Cardioprotection with inorganic nitrites}

Organic nitrites and nitrates have been used for a long time in the treatment of coronary artery diseases. More recently it has turned out that these compounds not only improve the ischaemic changes, but they can also suppress the generation of ventricular arrhythmias, resulting from ischaemia and reperfusion. For example, we have evidence that increasing nitric oxide (NO) bioavailability by the administration of organic nitrites and nitrates, which are thought to act as NO donors, reduces the severity of arrhythmias that results from acute ischaemia and reperfusion in anaesthetized dogs. Although the precise mechanism of this antiarrhythmic effect of organic nitrites is not fully elucidated, it is almost certain that the protective effect can be associated with an increased nitric oxide bioavailability during ischaemia and reperfusion, and with the subsequent widespread regulative influence of nitric oxide on the various biological functions.

In the past decade it has become evident that the inorganic nitrite and nitrate, the natural metabolites of NO, which have been considered for a long time as inert molecules without further biological activity, may play an important physiological role in mediating the biological effects of nitric oxide. It has been recognised that these molecules can readily reduce back to NO, especially under reductive conditions, such as hypoxia or ischaemia, thus providing nitric oxide to the NO depleted tissues. This enzyme-independent NO formation might be particular important during ischaemia, when in the absence of oxygen, the NO production by nitric oxide synthase (NOS) enzymes becomes limited. Thus nitrite can serve as a fundamental natural store of $\mathrm{NO}$ that serves to maintain cardiac function under ischaemic conditions.

Our research group at the Department of Pharmacology and Pharmacotherapy of the Szeged University has a long interest in the exploration of the cardioprotective effects of nitric oxide. We are particularly interested in to examine the effects and the underlying mechanisms of nitric oxide on the ischaemia and reperfusion induced acute arrhythmias. Since Professor Julius Papp, a member of the Hungarian Academy of Sciences, during his chairmanship of our Department has been involved and mentored this research; we should like to tribute him on his $80^{\text {th }}$ birthday by providing a summary of our current achievements, relating to the cardioprotective effects of inorganic nitrates.

Keywords: arrhythmia, ischaemia/reperfusion, inorganic nitrites, nitric oxide, experimental study 


\section{Bevezetés}

A szív koszorúereinek károsodása nyomán fellépő iszkémiás szívbetegségek megelőzésére és kezelésére legrégebb óta alkalmazott gyógyszerek a nitrát-savak észterei. A szerves nitritek és nitrátok orvosi gyakorlatban történő elterjedése szorosan összefügg Alfred Nobel által felfedezett és 1864-ben szabadalmaztatott dinamit (nitroglicerin, glicerin trinitrát) felfedezésével, ugyanis a gyártás során, a munkásokon tapasztalt élettani hatások (értágulat, fejfájás, arckipirulás) orvosi vizsgálatok sorozatát indította el. Szerencse vagy zsenialitás kellett-e ahhoz, hogy a skót orvos Thomas Lauder Brunton (1844-1916), aki már évtizedek óta próbálkozott az amil-nitritkezeléssel anginás betegekben (1), valamint az angol klinikai farmakológus William Murrell (1853-1912) felismerje az összefüggést a nitroglicerin élettani hatásai és annak az orvosi gyakorlatban történő alkalmazási lehetőségei között? Mindenesetre William Murrell 1879-ben a Lancetben közölte, hogy a nitroglicerin hatékonyan csökkenti az angina pectoris tüneteit (2). Az azóta eltelt közel 150 év kísérletes és klinikai tapasztalata bizonyította, hogy a szerves nitritekből és nitrátokból enzimatikus és nem enzimatikus úton keletkező nitrogén-monoxid (NO) az a molekula, amely az élettani hatásokat kiváltja és a terápiás hatást biztosítja. A jelenleg alkalmazott számos szerves nitrités nitrátkészítményt, az azonos hatásmechanizmusuk következtében, NO-donoroknak is nevezzük (3).

Az elmúlt évtized ígéretes felismerése volt, hogy a korábban inert molekulának tekintett szervetlen nitritek és nitrátok is képesek önálló farmakológiai hatással rendelkezni $(4,5)$. Ezek a molekulák, amelyek a nitrogén-monoxid (NO) természetes oxidatív metabolitjai, iszkémiás körülmények között (hipoxia, anoxia, csökkent $\mathrm{pH}$ ) könnyen nitrogén-monoxiddá redukálódnak (6). Ez az ún. „nem enzimatikus” NO-képződés különösen fontos lehet iszkémiában, amikor a nitrogén-monoxidot szintetizáló (NOS) enzimek müködése az oxigénhiány következtében korlátozottá válik. Ilyenformán a nitritek a nitrogén-monoxid alapvető, természetes raktárának tekinthetők $(7,8)$.

\section{A szervetlen nitritek antiaritmiás hatása}

A Szegedi Tudományegyetem Farmakológiai és Farmakoterápiai Intézetének Hemodinamikai Laboratóriumában több mint 20 éve folynak kutatások a nitrogén-monoxid kardioprotektív hatásának kimutatására. A munkacsoport elsőként igazolta, hogy a prekondicionálással kialakítható szívvédelem egyik meghatározó szereplője, a prekondicionáló inger hatására a koszorúerek endothelsejtjeiből és a szívizomsejtekből felszabaduló nitrogén-monoxid, amely széles körü biológiai hatásánál fogva számos olyan folyamatot indít el, amelyek eredményeképpen a szívizom átmenetileg védetté vagy legalábbis toleránsabbá válik az iszkémiás stressz, önmagában akár letális hatásaival szemben $(9,10)$. A prekondicionáló inger, legyen akár rövid koszorúér-elzárás (9), a szív magas frekvenciával történő ingerlése (11-13) vagy erőteljes fizikális terhelés (14), közös jellemzője, hogy fokozzák a nitrogén-monoxid-szintáz enzimek (NOS) aktivitását, ezen keresztül az NO szintézisét. Az NO biológiai hozzáférhetőségének iszkémia alatti megtartása, nota bene javítása, számottevően hozzájárul az iszkémia/reperfúzió (I/R) okozta súlyos kamrai aritmiákkal szemben megnyilvánuló azonnali (korai), illetve a 24 óra elteltével megnyilvánuló (késői) védőhatáshoz (15). Ezt igazolják azok a vizsgálataink is, amelyekben kimutattuk, hogy a NO leadására képes (NO-donorok) vegyületek, mint például az izoszorbid-mononitrát (16) vagy a KATP-csatorna-nyitó hatással is rendelkező nicorandil (17) jelentős mértékben csökkentik az I/R okozta súlyos kamrai ritmuszavarokat.

Az utóbbi 10-15 év kísérletes és klinikai kutatásainak az a felismerése, hogy a szerves nitrátok és nitritek mellett, az NO-metabolizmus és a táplálékkal bejutott szervetlen nitritek és nitrátok is, mint NO-donorok, terápiás értékkel bírhatnak, újabb „lökést” adott az NO-kutatásnak (18). A jelen összefoglaló rövid áttekintést ad azokról a vizsgálatokról, amelyeket a Szegedi Tudományegyetem Farmakológiai és Farmakoterápiai Intézetében a szervetlen nitritek antiaritmiás hatásának és a benne szerepet játszó mechanizmusok felderítésére végeztünk.

\section{A szervetlen nitritek „korai"” antiaritmiás hatása}

A szervetlen nitritek hatását vizsgáló első kísérleteink azok voltak, amelyek a korábban vérnyomáscsökkentésre használt nitroprusszid-nátrium (SNP) akut koszorúér-okklúzió és reperfúzió okozta, gyakran fatális kimenetelü kamrai ritmuszavarokra gyakorolt hatását vizsgáltuk (19). Kimutattuk, hogy az SNP közvetlenül az iszkémia előtt és alatt adva számottevően csökkentette a kamrai aritmiák számát és gyakoriságát (1. ábra) és ez a hatás összefüggésbe hozható volt az SNP-ből felszabaduló nitrogén-monoxid gap junkciós (GJ) csatornákat szabályozó hatásával $(19,20)$.

Az élelmiszeriparban tartósítószerként, illetve színek fixálására alkalmazott legegyszerübb nitritvegyület a nátrium-nitrit, amely kémiailag a nátrium salétromsavas sója. Oxigénnel érintkezve nitráttá alakul, míg oxigénhiányos reduktív közegben, NO képződhet belőle. Miután vízben jól oldódik, könnyen hozzáférhető és olcsó, elsődlegesen a nátrium-nitritet használják a szervetlen nitritek biológiai hatásait felderítő kutatásokban. Jelenleg a klinikai gyakorlatban egyes keringési zavarok esetén értágító hatása miatt, illetve bizonyos légzészavarok esetén hörgőtágító hatása miatt alkalmazzák. 

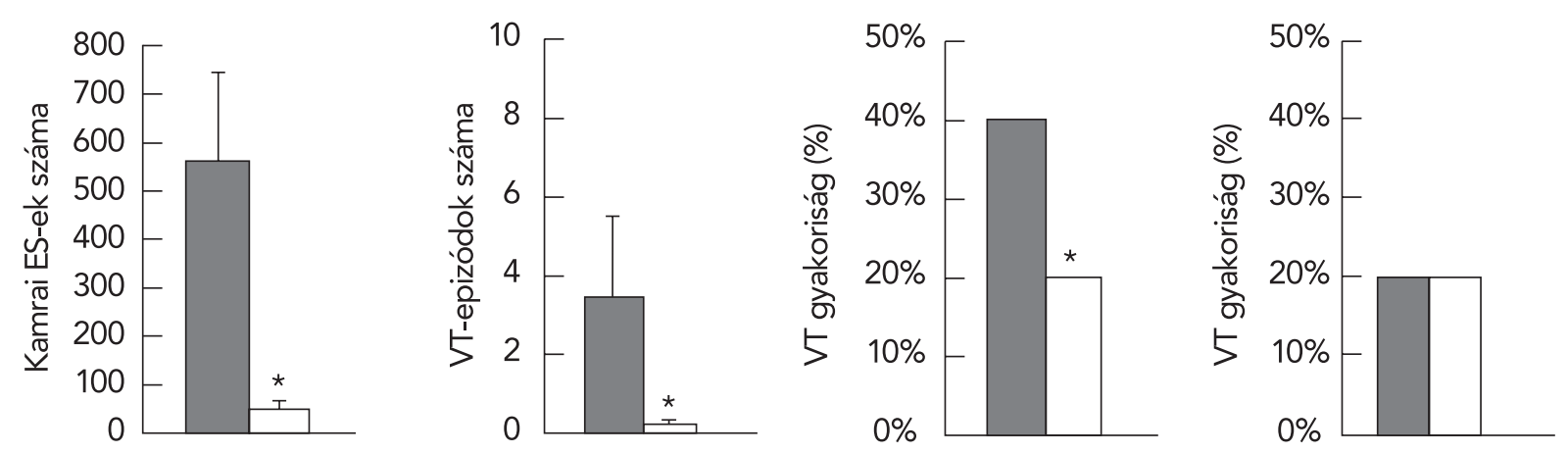

1. ÁBRA. A kamrai aritmiák száma és gyakorisága a bal koszorúér descendens anterior ágának 25 perces okklúziója alatt, kontroll és nitroprusszid-nátriummal kezelt kutyákban. A nitroprusszid-nátrium szignifikánsan csökkentette a kamrai extraszisztolék (ES) és tachycardiás (VT) epizódok számát, valamint a VT gyakoriságát, de számottevően nem befolyásolta az okklúzió alatti kamrafibrilláció (VF) előfordulását. Átlag士szórás, * $p<0,05$ a kontrollhoz képest

Ciánmérgezésben erős ciánmegkötő-képessége miatt ellenanyagként használják.

Munkacsoportunk 2010-ben kezdett vizsgálatokat a nátrium-nitrit, akut iszkémia és reperfúzió okozta kamrai ritmuszavarokra gyakorolt hatásának felderítésére. Az erre irányuló kísérleteinket jelentős mértékben motiválták azok a korábbi kísérletes és klinikai vizsgálatok, amelyek különböző kórfolyamatokban, a kis koncentrációban alkalmazott nátrium-nitritet hatékonynak találták $(4,7,18,21)$, ugyanakkor az iszkémia és reperfúziós aritmiákra gyakorolt hatás zömében ismeretlen volt. Ennek megfelelően vizsgálatokat terveztünk a nátrium-nitrit akut koszorúér-okklúzió és reperfúzió okozta kamrai aritmiákra kifejtett hatásának és hatásmechanizmusának vizsgálatára altatott kutyamodellben (22). Kísérleteinkben a nátrium-nitritet $0,2 \mu \mathrm{mol} \mathrm{kg}{ }^{-1} \mathrm{~min}^{-1}$ koncentrációban, intravénás infúzióban adtuk a kutyák két csoportjában. Az egyik csoportban a nitrit infúziót 20 perccel a bal koszorúér-artéria descendens anterior (LAD) ágának elzárása előtt indítottuk és az érelzárás teljes időtartama (25 perc) alatt fenntartottuk. Az állatok másik csoportjában az infúziót a LAD-elzárás alatt indítottuk, az ér felengedését megelőzően 10 perccel. A kísérletek során a rutin hemodinamikai paraméterek (artériás vérnyomás, bal kamrai szisztolés és diasztolés nyomás, pozitív és negatív dP/dt, szívfrekvencia, koszorúér-átfolyás) mellett, meghatároztuk a koszorúér-okklúzió alatti kamrai aritmiák (extraszisztolék, tachycardiás epizódok, kamrafibrilláció) számát és gyakoriságát. Az in situ kísérletekben követtük az iszkémia súlyosságát jellemző paramétereket (epikardiális ST-szakasz változás, totál aktivációs idő), valamint a szívszövet impedanciájában (rezisztencia, fázisszög) bekövetkező változásokat, amelyek a gap junkciós csatornák állapotára (nyitott/zárt) szolgálhatnak felvilágosítással. A kísérletek során bizonyos időpontokban vett vérmintákban mértük a plazma nitrát/nitrit (NOx) koncentrációját, illetve a reperfúziót követően vett szövetmintákban meghatároztuk a szuperoxid és 3-nitrotizozin (3-NT) szinteket, valamint kollaborációs partnereink (Elizabeth Murphy és munkatársai, Bethesda, USA) segítségével, fehérje S-nitrozilációs méréseket végeztünk.

Kimutattuk, hogy a nátrium-nitrit akár az okklúziót, akár a reperfúziós megelőzően olyan koncentrációban adva,

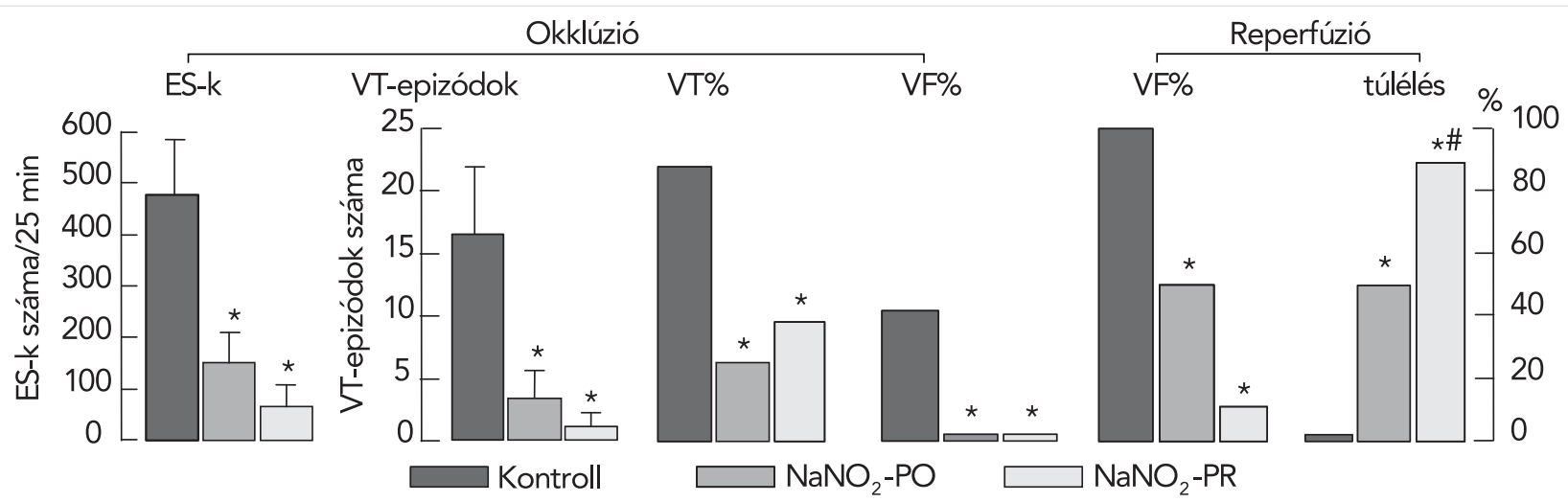

2. ÁBRA. A nátrium nitrit hatása a 25 perces iszkémia és reperfúzió során megjelenő kamrai ritmuszavarokra. A kontrollcsoporthoz képest, a nátrium nitrit mindkét kezelés (okklúzió előtt és alatt, illetve reperfúzió előtt) esetén szignifikánsan csökkentette a kamrai aritmiák számát és gyakoriságát, valamint növelte a túlélő állatok arányát. Ezen utóbbi hatás különösen számottevő volt, amennyiben az állatok a reperfúziót megelőzően kapták a nátrium nitrit infúziót. Átlag士szórás, *p<0,05 a kontrollhoz képest, \#p<0,05 az okklúzió előtt nitráttal kezelt csoporthoz képest. 
amely nem befolyásolja az artériás vérnyomást és a koszorúér-keringést, számottevően csökkentette az iszkémia és reperfúzió során megjelenő súlyos kamrai aritmiákat (2. ábra) (22). Az aritmiákkal szembeni védőhatás különösen kifejezett volt azokban a kutyákban, amelyekben a nitritet 10 perccel a reperfúzió előtt adtuk; ezeknek az állatoknak ugyanis több mint 90\%-a túlélte az okklúziós/reperfúziós inzultust (2. ábra). A nitrit infúzió számottevően csökkentette a koszorúér-okklúzió következtében bekövetkező iszkémiás elváltozások súlyosságát, így az epikardiális ST-szakasz-emelkedést és az elektromos aktiváció inhomogenitására utaló totális aktivációs idő megnyúlását (22). A nátrium-nitrit mindkét beadást követően számottevően mérsékelte az iszkémia/reperfúzió következtében megemelkedett oxidatív stressz termékek képződését. A reperfúziót követő szuperoxid- és a peroxinitrit-képződés mérésére szolgáló 3-NT-szintek szignifikánsan kisebbek voltak a nitrittel kezelt állatokban, mint az iszkémiás kutyákban (22).

Számos irodalmi adat utal arra, hogy az NO biológiai hozzáférhetőségének javítása az iszkémia alatt csökkenti a reperfúzió generálta szabadgyök-képződést (ROS) (23-25), amely hatás összefüggésbe hozható a reperfúziós aritmiák képződésének gátlásával (26). Bár az NO számos úton szabályozhatja a szuperoxid-képződést, az egyik legelfogadottabb elképzelés szerint az NO a mitokondriális komplexekre (elsődlegesen komplex I) hatva, azok poszttranszlációs S-nitrozilációja (SNO) révén csökkentik a szuperoxid termelődését $(27,28)$. A kardioprotektív hatás feltételezett mechanizmusa, hogy a reperfúzió korai fázisában a fehérjék cisztein oldalláncaihoz reverzibilisen kapcsolódó NO megóvja a fehérjét az szuperoxid irreverzibilis oxidáló hatásától $(29,30)$.

Kísérleteinkben SNO-RAC-analízist végezve meghatároztuk az SNO-fehérjék és peptidek számát és azonosítottuk azokat a fehérjéket és aminosav láncokat, amelyek fokozott SNO-t mutattak. Megállapítottuk, hogy azokban az állatokban, amelyekben a nitritet a reperfúziót megelőzően adtuk számottevően emelkedett az SNO-fehérjék és peptidek száma (22). Érdekességképpen, ezen fehérjék közül számos protein esetében a prekondicionálást követően is fokozott SNO-t találtak (31, 32). Ilyen például a SERCA2a, amelynek az S-nitrozilációja fokozza a fehérje aktivitását (32) és amelynek eredményeképpen a javuló kalcium reuptake az intracelluláris kalciumszint csökkentése által szerepet játszhat az aritmiákat csökkentő hatásban. Esetünkben számos olyan fokozott SNO-képződést mutató fehérjét azonosítottunk, amelyek fontos szereplői a szív metabolizmusának és energiaháztartásának. A glikolízis és a Szent-Györgyi-Krebs-ciklus több enzime is, amelyek mind thiol csoportokban, mind fémion központi magban gazdagok, ezáltal könnyen reakcióba lépnek az NO-val, fokozott SNO-t mutatott (22). Ennek szerepe lehet a szívizom mechanikai (kontraktilis) és energetikai funkciójának reperfúziót követő gyorsabb helyreállásában (29). Ugyancsak feltételezhető, hogy a citrát-ciklus enzimeinek az NO általi reverzibilis gátlása lassítja az elektrontranszport lánc (ETC) elektron folyását és ezáltal a szuperoxid képződését (24). Számos, a mitokondrium szerkezetében és funkciójában szerepet játszó fehérje is fokozott SNO-képződést mutatott azokban a kutyákban, amelyekben a nátrium-nitritet 10 perccel a reperfúzió megelőzően adtuk (22). Ezzel szemben, meglepetésünkre, szinte alig találtunk fokozott SNO-t mutató fehérjét azokban az állatokban, amelyek a nitritet az okklúzió előtt és alatt kapták, mindannak ellenére, hogy az aritmiákkal és az iszkémiás elváltozásokkal szemben mutatott védőhatás jelen volt és az oxidatív stressz termékek (szuperoxid, peroxinitrit) is szignifikánsan csökkentek (22). Az SNO-képződés hiányára több magyarázat is szolgálhat; feltételezhető, hogy az iszkémia előtt és alatt folytatott nitritkezelés esetén a nitrit nem NO-vá redukálódik, hanem nitráttá oxidálódik. Ezt támasztaná alá, hogy ezekben az állatokban a nitrátszintek folyamatos emelkedést mutattak (22). Az is elképzelhető, hogy a nitrit hosszabb infúziója esetén (20 perc okklúzió előtt és 25 perc okklúzió alatt, szemben a másik nitrit kezelt csoport 10 percig tartó, iszkémia alatti adásával) a nitritből keletkezett NO elsődlegesen nem a nitrozilációs utat követi, hanem más mechanizmusokon keresztül fejti ki a védőhatását. Ezek közé tartozhat a NO közvetlen kapcsolódása vastartalmú enzimekkel, mint pl. a szolúbilis guanilát-cikláz vagy a mitokondriális citokróm-oxidáz (complex IV) (33), a neutrofil szuperoxid-képződés NO közvetítette gátlása (34), valamint az antioxidáns enzimek és szációs utak (pl. cGMP/PKG) NO-függő aktivációja $(35,36)$. $A z$, hogy az NO éppen milyen reakcióba lép befolyásolja az NO és a vele reagáló molekulák pillanatnyi lokális koncentrációja vagy az a közeg (pl. reduktív/oxidatív), amelyben az NO keletkezett és pillanatnyilag jelen van. Felvetődik egy másik lehetséges mechanizmus is, amely szerint folyamatos NO-forrás jelenlétében (NOdonorok, eNOS/iNOS-aktiváció) az NO a GSNO-útvonalon keresztül a fehérjéket S-glutationilálja és mintegy „glutation-sapkát” képezve a fehérje oldalláncok körül megvédi a fehérje thiol csoportjait az irreverzibilis oxidációtól (37). Kísérleteinkben vizsgáltuk ezt a lehetőséget és megállapítottuk, hogy azokban az állatokban, amelyekben a nitritet az okklúzió előtt és alatt adtuk, a fehérje S-glutationiláció erőteljesebb volt, mint akár a kontrollcsoportban, akár abban az esetben, ha a nitritet 10 perccel a reperfúzió előtt adtuk (22). Eredményeink alátámasztották azt a hipotézist, hogy a fehérje S-glutationiláció képes védőhatást eredményezni $(38,39)$.

Munkánk elsőként igazolta, hogy a szervetlen nitritvegyületek, esetünkben a nátrium-nitrit, olyan koncentrációban alkalmazva, amely az általános hemodinamikai paramétereket (vérnyomás, szívfrekvencia, koszorúér-keringés) számottevően nem befolyásolják, jelentős 
védőhatást biztosít az iszkémia és reperfúzió során kialakuló akut ritmuszavarokkal szemben. Ez az antiaritmiás hatás különösen kifejezett, ha a nitritet az iszkémia alatt, de a reperfúziót megelőzően adjuk. Ebben az esetben az állatok 92\%-a túlélő volt, szemben a kontrollcsoporttal, ahol egyetlen állat sem élte túl a kombinált okklúziós és reperfúziós inzultust. A reperfúziós aritmiák nagyfokú gátlásának egyik oka lehet a reperfúziós károsodás nitrit (NO) általi mérséklése, az oxidatív stressz termékek (szuperoxid, peroxinitrit) termelődésének csökkentése, amelyben a fehérje S-nitrozilációs és S-glutationilációs mechanizmusok játszanak szerepet (22). Amennyiben a hatás és hatásmechanizmus felderítésén túlmenően az állatkísérletes eredményeinkből a klinikai gyakorlat számára is hasznosítható következtetést kívánnánk levonni, felvetődik a nátrium-nitrit adás potenciális kedvező hatása az akut szívmütéti beavatkozások esetén, amikor iszkémiás szívbetegség esetén, a koszorúér tágítása, illetve megnyitása előtt adva, számottevően csökkentheti a reperfúziós károsodás mértékét és javíthatja a túlélés esélyét.

\section{A szervetlen nitritek „késői”" antiaritmiás hatása}

Mára elfogadott tény, hogy a nitrogén-monoxid kulcsfontosságú trigger és mediátor szerepet tölt be a különböző ingerekkel (koszorúér-okklúzió, magas frekvenciájú szívingerlés, erőteljes fizikális aktivitás stb.) kialakítható szívvédelemben (11-14). Számos saját és mások által végzett kísérletes adat bizonyítja, hogy a NO széles körü biológiai hatásánál fogva, különböző folyamatok egyidejű szabályozása révén, meglehetősen összetett módon alakítja ki a kardioprotektív hatást (pl. 40-43). Az is elfogadott tényként kezelhető, hogy a NO biológiai hozzáférhetőségének biztosításával (pl. prekondicionálás, NO-donorok adása) nemcsak rövid, de hosszabb távon is kialakítható a védőhatás.
Ez az ún. „késői védőhatás” kb. 20-24 órával a prekondicionáló inger vagy az NO-donor beadását követően észlelhető és a hatás akár 48 és 72 óra múlva is kimutatható (11-14, 44). A prekondicionálással előidézett késői védőhatásban igazoltan $(45,46)$, az NO-donorok esetében feltételezhetően szerepe van az indukálható nitrogén-monoxid-szintáz enzim (iNOS) NO általi aktivációjának és ezáltal a folyamatos NO képződésnek, amely az iszkémia bekövetkezte esetén, megfelelő NO hozzáférhetőséget biztosítva, ellensúlyozza az iszkémia endotheliális NOS (eNOS) általi NO-szintézist korlátozó hatását.

Mindezen előzmények ismeretében felmerült, hogy vajon a szervetlen nátrium-nitrit képes-e késői kardioprotektív hatást kiváltani, s amennyiben igen, akkor a hatás miképpen jön létre. Ezen utóbbi kérdés azért válik fontossá, mivel a nitrit beadásakor - ha az a klasszikus protokollnak megfelelően 24 órával az iszkémia előtt történik - a szervezetben fiziológiás környezet van, amelyben a nitrit elsődlegesen nitráttá oxidálódik és a nitrit NO-gázzá történő konverziójának esélye csekély; nagyban függ a vérben lévő nitrit-reduktázok (deoxi-hemoglobin és xantin-oxidoreduktáz) aktivitásától (18).

A nátrium-nitrit késői antiaritmiás hatásának vizsgálatára a nátrium-nitritet $0,2 \mu \mathrm{mol} \mathrm{kg}^{-1} \mathrm{~min}^{-1}$ koncentrációban 20 percen keresztül intravénásan adtuk, majd 24 óra elteltével a bal koszorúér-artéria descendens anterior ágát 25 percre elzártuk. Kimutattuk, hogy az iszkémiás kontrollcsoporthoz képest, a nitrittel kezelt állatokban az okklúzió alatti kamrai aritmiák száma és súlyossága szignifikánsan csökkent és az állatok mintegy 50\%-a túlélte az okklúziós/reperfúziós inzultust (3. ábra) (47). Ezekben a kísérletekben azt is vizsgáltuk, vajon, hasonlóan a prekondicionálással előidézett késői védőhatáshoz, az NO általi iNOS-aktiváció következtében termelődő több NO-útnak $(45,46)$ szerepe van-e a nitrit késői antiaritmiás hatásában. Ennek a kimutatására az iNOS gátlószerét a S-(2-aminoetil)-izotioureát (AEST; 2,0 mg kg-1; iv.) adtuk intravénásan a

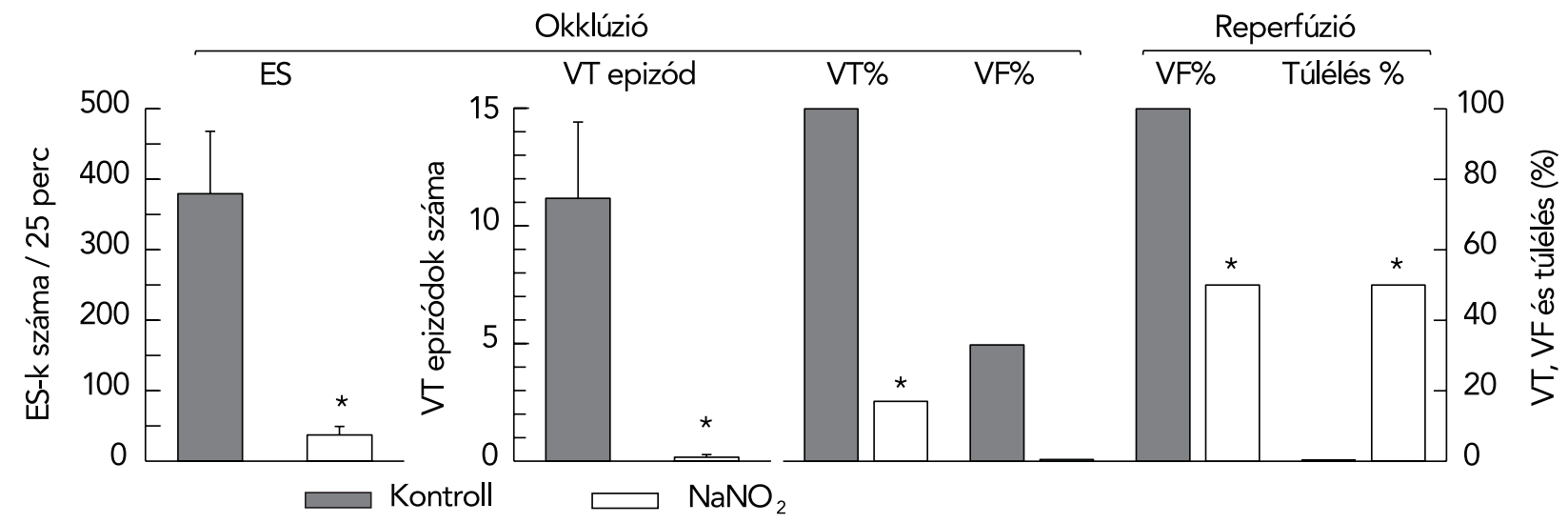

3. ÁBRA. A nátrium-nitrit késői antiaritmiás hatása. A kontrollcsoporthoz képest a 24 órával korábban intravénás infúzióban adott nátrium-nitrit szignifikánsan csökkentette az okklúzió és reperfúzió során kialakuló kamrai aritmiák számát és súlyosságát, valamint növelte a túlélés gyakoriságát. Átlag士szórás, * $\mathrm{p}<0,05$ a kontrollhoz képest 
nitrit infúziót, majd 24 óra elteltével a koszorúér-okklúziót megelőzően. Vizsgálatainkból kiderült, hogy a beadást követően, a nitrit nagy része nitráttá alakul, amely 24 óra múlva a vérben a nitrátszint-emelkedésében és a nitritszint ezzel párhuzamos csökkentésében nyilvánul meg. Bár az iNOS-enzim aktivációja kimutatható volt, eredményeink arra utaltak, hogy a nitrittel kezelt állatokban az iszkémia során kimutatható jobb NO-kínálat elsődlegesen a nitrát-nitrit-NO redukcióból nem pedig az NO általi iNOS-aktivációból származik (47). Néhány, a nitrit késői kardioprotektív hatását célzó vizsgálat eredményei arra utaltak, hogy 24 órával a nitritadást követően az infarktus kiterjedése és a hepatikus reperfúziós károsodás számottevően csökken (48) és ebben a hatásban a mitokondriális komplexek, különösen a komplex I, S-nitrozilációval történő poszttranszlációs módosulása játszik szerepet $(49,50)$. Miután ezek az előzetes kísérletek számos kérdést vetettek fel, célszerünek látszott, hogy in vivo körülmények között megvizsgáljuk, vajon a nitrit késői antiaritmiás hatása milyen mértékben köszönhető a mitokondrium szerkezetében és müködésében bekövetkező változásoknak. Transzmissziós elektron-mikroszkópos felvételek kvalitatív és kvantitatív analízise alapján megállapítottuk, hogy az általunk alkalmazott 25 perces iszkémia és reperfúzió számottevő szerkezetbeli változásokat idéz elő a mitokondriumban; a mitokondrium megduzzad, a mitokondriális mátrix cristae állománya felbomlik, a mitokondriális károsodásra jellemző kvalitatív paraméterek, mint a mitokondrium átmérő, terület, Feret-átmérő számottevően csökkennek, míg a gömbformálódási képesség fokozódik. Ezek a változások a sejt minden szegmensében (szubszarkolemmális, intermiofibrilláris, perinukleáris) egyaránt kimutatható. Nitrittel történő kezelést követően ezek az iszkémia által előidézett strukturális elváltozások számottevően csökkennek, a sejtben a mitokondriumok épsége nagyrészt megőrződik, jelezve, hogy a mitokondriumok normális szerkezetének nitrit általi fenntartása hozzájárulhat a védőhatáshoz.

Felmerül a kérdés, vajon a mitokondriális struktúra megőrzése mennyiben jelenti a mitokondrium funkciójának megtartását. Ezt a mitokondriális légzés és ATP-szintézis meghatározásával követük. A mitokondriális légzést Clarke-típusú oxigén elektród segítségével mértük és különböző légzési paraméterekben, így a komplex I (CI) és komplex II (CII) függő oxidatív foszforiláció (OXPHOS), az elektron transzportlánc (ETC), a respirációs kontrollarány (respiratory control ratio, RCR), valamint a $\mathrm{P} / \mathrm{E}$ kontroll-kapcsolási arány (P/E control coupling ratio) bekövetkező változásokkal jellemeztük. Megállapítottuk, hogy a 25 perces iszkémia és 2 perces reperfúzió hatására a mitokondrium Cl-függő légzési paraméterei (OXPHOS, ETC, RCR) szignifikánsan csökkennek, míg a P/E arány számottevően nem változik a nem iszkémiás kontrollhoz képest. Ezek a változások arra utalnak, hogy az ilyen időtartamú iszkémia mintegy negyedére (24\%) csökkenti a mitokondrium légzési kapacitását és ez a mitokondriális komplexek (elsődlegesen a $\mathrm{Cl}$ ) gátlásán keresztül valósul meg. $\mathrm{A}$ légzési lánc komplexeinek iszkémia általi gátlása együtt járt az ATP-szintézis csökkentésével valamint a szabad gyökök, így a szuperoxid és annak károsító terméke a peroxinitrit termelődésének fokozódásával.

A nátrium-nitrit 24 órával az iszkémia/reperfúziót megelőzően adva önmagában (iszkémia nélkül) is gyengítette, iszkémiás körülmények között pedig, az iszkémiás kontrollhoz képest, tovább csökkentette a mitokondrium légzési kapacitását, amely az OXPHOS (48\%), az RCR és a $P / E$-arány számottevő csökkenésében nyilvánult meg. Ugyanakkor a nitrit az iszkémia okozta ATP-csökkenést nem befolyásolta, míg az oxidatív stressz termékek (szuperoxid, peroxinitrit) képződését szignifikánsan gátolta. Eredményeink arra utalnak, hogy a nitrit késői védőhatásában a mitokondrium légzési funkciójára gyakorolt hatás szerepet játszik, azonban a korábbi feltevésekkel ellentétben (48-50), mi a nitrithatás támadáspontjának elsődlegesen nem a mitokondriális komplexeket, hanem a foszforilációs rendszert tekintjük. Ezt az elképzelést támasztja alá, hogy a komplexek és a foszforilációs rendszer FCCP-vel történő szétkapcsolása esetén, mind az iszkémiás kontroll, mind a nitritkezelt csoportban az ETC csökkenése hasonló volt, míg az OXPHOS a nitrittel kezelt állatokban szignifikánsan tovább csökkent, így a P/E-ráta (OXPHOS/ETC) is erőteljesen csökkent az iszkémiás kontrollhoz képest. Ennek alapján felvetjük, hogy a nitrit elsődlegesen a foszforilációs rendszerre hatva, mintegy „feedback” módon csökkenti a légzési lánc komplexeinek müködését. Feltételezhető, hogy az iszkémia alatt a nitritből keletkezett NO a foszforilációs rendszer valamelyik tagjára, így például az ATP-szintáz, a foszfát transzporter vagy az ADP/ATP transzlokációját végző ANT, hatva hozhatja létre hatását. Elképzelhető, hogy a nitrit módosítja az ATP-szintáz és ciklofillin-D interakcióját, amely kapcsolódásnak szerepe van a mitokondriális permeabilitást szabályozó pórusok (MPTP) képződésében és nyitásában, ezáltal az iszkémia és reperfúzió hatására kialakuló ATP-csökkenésben és szabadgyök-termelésben (51). Amennyiben a nitrit meggátolja a belső mitokondriális membrán proteinjei és a ciklofillin-D közötti kapcsolat következtében kialakuló pórusformálódást vagy nyitást, úgy az protektív hatásokat, így az ATP-vesztés mérséklését és a ROS-képződést csökkenését, idézhet elő $(51,52)$. Kísérletes bizonyítékok utalnak arra, hogy a ciklofillin-D 203 alegysége, amely szükséges a ciklofillin-D aktivációjához és következésképpen az MPTP-nyitáshoz (53), NO-gazdag közegben S-nitroziláció révén SNO-t képez (54), meggátolva a ciklofillin-D pórusképzéshez vezető aktivációját.

Bár hipotézisünk alátámasztására saját kísérletes adatokkal nem rendelkezünk, a fentiek alapján csábító feltételezni, hogy a nitrit késői védőhatásában a mitokondriális fehérjék és enzimek S-nitrozilációja, mint 
alapvető protektív hatású mechanizmus (55) fontos szerepet játszik.

\section{Következtetések}

Összefoglalásképpen megállapíthatjuk, hogy a szervetlen nátrium-nitrit mind akut, mind hosszabb (24 óra) időtávon belül számottevő védőhatást biztosíthat a heveny iszkémia és reperfúzió során fellépő, gyakran fatális kimenetelü aritmiákkal szemben, amelyek felelössé tehetők a hirtelen szívhalál kialakulásáért (56). Nagy valószínűséggel feltételezhető, hogy a nitrit kardioprotektív hatása a belöle iszkémiás körülmények alatt könynyen képződő nitrogén-monoxidnak köszönhető. Ez az ún. „nem enzimatikusan” képződő nitrogén-monoxid pótolja az iszkémia következtében kieső NO-hiányt és jobb NO biológiai hozzáférhetőséget biztosítva rövidebb és hosszabb távon is védi a szívet az iszkémia/ reperfúzió káros következményeivel (pl. ritmuszavarok) szemben. Bár a nitrogén-monoxidnak széles körü szabályozó szerepe van a különböző biológiai folyamatokban, amelyek különböző módokon és szinteken érvényesülhetnek a védöhatásban, nagy valószínüséggel feltételezhető, hogy sejtszinten, megfelelő NO biológiai hozzáférhetőség mellett, a fehérjék S-nitrozilációja lehet az alapvető mechanizmus, amely szerepet játszik a védőhatás kialakításában.

\section{Irodalom}

1. Brunton TL. On the use of nitrite of amyl in angina pectoris. The Lancet 1867; 2: 97. https://doi.org/10.1016/S0140-6736(02)51392-1 2. Murrell W. Nitro-glycerine as a remedy for angina pectoris. The Lancet 1879; 113: 225-227. https://doi.org/10.1016/S0140 6736(02)46032-1

3. Miller MR, Megson IL. Recent developments in nitric oxide donor drugs. Br J Pharmacol 2007; 151: 305-321. https://doi.org/10.1038/ sj.bjp.0707224

4. Kevil CG, Lefer DJ. Review focus on inorganic nitrite and nitrate in cardiovascular health and disease. Cardiovasc Res 2011; 89: 489-491. https://doi.org/10.1093/cvr/cvq409

5. Kevil CG, Kolluru GK, Pattillo CB, et al. Giordano T. Inorganic nitrite therapy: historical perspective and future directions. Free Rad Biol Med 2011; 51: 576-593. https://doi.org/10.1016/j.freeradbiomed.2011.04.042

6. Zweier JL, Wang P, Samouilov A, et al. Enzyme-independent formation of nitric oxide in biological tissues. Nature Medicine 1995; 1 804-809. https://doi.org/10.1038/nm0895-804

7. Lefer DJ. Nitrite therapy for protection against ischemia-reperfusion injury. Am J Physiol Renal Physiol 2006; 290: F777-F778. https://doi.org/10.1152/ajprenal.00470.2005

8. Lundberg JO, Carlström M, Larsen FJ, et al. Roles of dietary inorganic nitrate in cardiovascular health and disease. Cardiovasc Res 2011; 89: 525-532. https://doi.org/10.1093/cvr/cvq325

9. Végh Á, Komori S, Szekeres L, et al. Antiarrhythmic effects of preconditioning in anaesthetised dogs and rats. Cardiovasc Res 1992 26: 487-495. https://doi.org/10.1093/cvr/26.5.487

10. Végh Á, Szekeres L, Parratt JR. Preconditioning of the ischaemic myocardium; involvement of the L-arginine-nitric oxide pathway. $\mathrm{Br} \mathrm{J}$ Pharmacol 1992; 107: 648-652. https://doi.or- g/10.1111/j.1476-5381.1992.tb14501.x

11. Végh Á, Papp JGy, Parratt JR. Prevention by dexamethasone of the marked antiarrhythmic effects of preconditioning induced $20 \mathrm{~h}$ after rapid cardiac pacing. Br J Pharmacol 1994; 113: 1081-1082. https://doi.org/10.1111/j.1476-5381.1994.tb17104.x

12. Kis A, Végh Á, Papp JGy, et al. Repeated cardiac pacing extends the time during which canine hearts are protected against ischaemia-induced arrhythmias: role of nitric oxide. J Mol Cell Cardiol 1999; 31: 1229-1241. https://doi.org/10.1006/jmcc.1999.0955

13. Kis A, Végh Á, Papp JGy, et al. Pacing-induced delayed protection against arrhythmias is attenuated by aminoguanidine, an inhibitor of nitric oxide synthase. Br J Pharmacol 1999; 127: 1545-1550. https://doi.org/10.1038/sj.bjp.0702695

14. Babai L, Szigeti Z, Parratt JR, et al. Delayed cardioprotective effects of exercise in dogs are aminoguanidine sensitive: possible involvement of nitric oxide. Clin Sci 2002; 102: 435-445. https://doi. org/10.1042/cs1020435

15. Parratt JR, Végh Á. Coronary vascular endothelium, preconditioning and arrhythmogenesis. In: Lewis MJ, Shah A, editors. Endothelial Modulation of Cardiac Function. Amsterdam; Harwood Academic Publishers; 1997. P. 237-254.

16. György K, Végh Á, Rastegar MA, et al. Isosorbide-2-mononitrate reduces the consequences of myocardial ischaemia, including arrhythmia severity: implications for preconditioning. J Cardiovasc Drugs Ther 2000; 14: 481-488. https://doi.org/10.1023/A:1007832921391 17. Végh Á, György K, Papp JGy, et al. Nicorandil suppressed ventricular arrhythmias in a canine model of myocardial ischaemia. Eur J Pharmacol 1996; 305: 163-168. https://doi.org/10.1016/00142999(96)00166-5

18. Dejam A, Hunter CJ, Schechter AN, et al. Emerging role of nitrite in human biology. Blood Cells Molecules and Diseases 2004; 232: 423-429. https://doi.org/10.1016/j.bcmd.2004.02.002

19. Gönczi M, Papp R, Kovács M, et al. Modulation of gap junctions by nitric oxide contributes to the anti-arrhythmic effect of sodium nitroprusside. Br J Pharmacol 2009; 156: 786-793. https://doi. org/10.1111/j.1476-5381.2008.00089.x

20. Végh Á, Gönczi M, Miskolczi G, et al. Regulation of gap junctions by nitric oxide influences the generation of arrhythmias resulting from acute ischemia and reperfusion in vivo. Frontiers in Pharmacology 2013; 4: 76, 1-10. https://doi.org/10.3389/fphar.2013.00076

21. Gonzalez FM, Shiva S, Vincent PS, et al. Nitrite anion provides potent cytoprotective and antiapoptotic effects as adjunctive therapy to reperfusion for acute myocardial infarction. Circulation 2008; 117 : 2986-2994. https://doi.org/ 10.1161/CIRCULATIONAHA.107.748814 22. Kovács $M$, Kiss $A$, Gönczi $M$, et al. Effect of sodium nitrite on ischaemia and reperfusion-induced arrhythmias in anaesthetized dogs: is protein S-nitrosylation involved? PloS One 2015; 24 : 10(4):e0122243. https://doi.org/10.1371/journal.pone.0122243

23. Iwase H, Robin E, Guzy RD, et al. Nitric oxide during ischemia attenuates oxidant stress and cell death during ischemia and reperfusion in cardiomyocytes. Free Radic Biol Med 2007; 43: 590-599. https://doi.org/10.1016/j.freeradbiomed.2007.05.017

24. Burwell LS, Brookes PS. Mitochondria as a target for the cardioprotective effects of nitric oxide in ischemia-reperfusion injury. Antioxid Redox Signal 2008; 10: 579-599. https://doi.org/10.1089/ ars.2007.1845

25. Korge $P$, Ping P, Weiss JN. Reactive oxygen species production in energized cardiac mitochondria during hypoxia/reoxygenation: modulation by nitric oxide. Circ Res 2008; 103: 873-880. https://doi. org/10.1161/CIRCRESAHA.108.180869

26. Kiss A, Juhász L, Seprényi Gy, et al. The role of nitric oxide, superoxide and peroxynitrite in the anti-arrhythmic effects of preconditioning and peroxynitrite infusion in anaesthetized dogs. $\mathrm{Br} J$ Pharmacol 2010; 160: 1263-1272. https://doi.org/10.1111/j.14765381.2010.00774.x 
27. Davis KL, Martin E, Turko IV, et al. Novel effects of nitric oxide. Annu Rev Pharmacol Toxicol 2001; 41: 203-236.

28. Chouchani ET, Methner C, Nadtochiy SM, et al. Cardioprotection by S-nitrosation of a cysteine switch on mitochondrial complex I. Nat Med 2013; 19: 753-759. https://doi.org/10.1038/nm.3212

29. Kohr MJ, Sun J, Aponte A, et al. Simultaneous measurement of protein oxidation and S-nitrosylation during preconditioning and ischemia/reperfusion injury with resin-assisted capture. Circ Res 2011; 108: 418-426. https://doi.org/10.1161/CIRCRESAHA. 110.232173

30. Murphy E, Steenbergen C. Mechanisms underlying acute protection from cardiac ischemia-reperfusion injury. Physiol Rev 2008; 88: 581-609. https://doi.org/10.1152/physrev.00024.2007

31. Kohr MJ, Sun J, Aponte A, et al. Simultaneous measurement of protein oxidation and S-nitrosylation during preconditioning and ischemia/reperfusion injury with resin-assisted capture. Circ Res 2011; 108: 418-426. https://doi.org/10.1161/CIRCRESAHA.110.232173

32. Sun J, Morgan M, Shen RF, et al. Preconditioning results in S-nitrosylation of proteins involved in regulation of mitochondrial energetics and calcium transport. Circ Res 2007; 101: 1155-1163. https://doi.org/10.1161/CIRCRESAHA.107.155879

33. Shiva S, Sack MN, Greer JJ, et al. Nitrite augments tolerance to ischemia/reperfusion injury via the modulation of mitochondrial electron transfer. JEM 2007; 204: 2089-2102. https://doi.org/ 10.1161/CIRCRESAHA.107.155879

34. Clancy RM, Leszczynska-Piziak J, Abrahanson SB. Nitric oxide, an endothelial cell relaxing factor, inhibits neutrophil superoxide anion production via a direct action on the NADPH oxidase. J Clin Invest 1992; 90: 1116-1121. https://doi.org/10.1172/JCl115929

35. Tripathi $P$, Misra MK. Therapeutic role of L-arginine on free radical scavenging system in ischemic heart diseases. Indian J Biochem Biophys 2009; 46: 498-502.

36. Inserte J, Hernando CV, Vilardosa U, et al. Activation of cGMP/ protein kinase $\mathrm{G}$ pathway in postconditioned myocardium depends on reduced oxidative stress and preserved endothelial nitric oxide synthase coupling. J Am Heart Assoc 2013; 2: e005975. https://doi. org/10.1161/JAHA.112.005975

37. West MB, Hill BG, Xuan YT, et al. Protein glutathiolation by nitric oxide: an intracellular mechanism regulating redox protein modification. FASEB J 2006; 20: 1715-1717. https://doi.org/10.1096/fj.065843fje

38. Foster DB, Van Eyk JE, Marbán E, et al. Redox signaling and protein phosphorylation in mitochondria; progress and prospects. J Bioenerg Biomembr 2009; 41: 159-168. https://doi.org/ 10.1007/ s10863-009-9217-7

39. Pimentel D, Haeussier DJ, Matsui R, et al. Regulation of cell physiology and pathology by protein S-glutathionylation: lessons learned from the cardiovascular system. Antioxid Redox Signal 2012; 16: 524-542. https://doi.org/10.1089/ars.2011.4336

40. Parratt JR, Végh Á. Coronary vascular endothelium, preconditioning and arrhythmogenesis. In: Lewis MJ, Shah A. editors. Endothelial Modulation of Cardiac Function. Amsterdam: Harwood Academic Publishers; 1997. P. 237-254. https://doi.org/10.1007/ s003950050091

41. Jonas SP, Bolli R. The ubiquitous role of nitric oxide in cardioprotection. J Mol Cell Cardiol 2006; 40: 16-23. https://doi.org/10.1016/j. yjmcc.2005.09.011
42. Schwartz PJ, Diem R, Dun NJ, et al. Endogenous and exogenous nitric oxide inhibits norepinephrine release from rat heart sympathetic nerves. Circ Res 1995; 77: 841-848. https://doi.org/10.1161/01. RES.77.4.841

43. Sears CE, Choate JK, Patterson DJ. NO-cGMP pathway accentuates the decrease in heart rate caused by cardiac vagal nerve stimulation. J Appl Physiol 1999; 86: 510-516.

44. Kaszala K, Végh Á, Papp JGy, et al. Time-course of the protection against ischaemia and reperfusion-induced ventricular arrhythmias resulting from brief periods of cardiac pacing. J Mol Cell Cardiol 1996; 28: 2085-2095. https://doi.org/10.1006/jmcc.1996.0201

45. Végh Á, Parratt JR. 1996. Delayed ischaemic preconditioning induced by drugs and by cardiac pacing. In. Myocardial Preconditioning. Wainwright CL, Parratt JR editors. R.G., Austin, Texas, U.S.A: Landes Company; 1996; p. 251-261. https://doi.org/10.1007/978-3662-22206-5 14

46. Bolli R, Manchikalapudi S, Tang XL, et al. The protective effect of late preconditioning against myocardial stunning in conscious rabbits is mediated by nitric oxide synthase. Evidence that nitric oxide acts both as a trigger and as a mediator of the late phase of ischemic preconditioning. Circ Res 1997; 81: 1094-107. https://doi. org/10.1161/01.RES.81.6.1094

47. Demeter-Haludka $V$, Juhász $L$, Kovács $M$, et al. Is there a role of iNOS activation in the delayed antiarrhythmic effect of sodium nitrite? Can J Physiol Pharmacol 2017; 95: 447-454. https://doi. org/10.1139/cjpp-2016-0357

48. Shiva S, Huang Z, Grubina R, et al. Deoxymyoglobin is a nitrate reductase that generates nitric oxide and regulates mitochondrial respiration. Circ Res 2007; 100: 654-661. https://doi.org/10.1161/01. RES.0000260171.52224.6b

49. Shiva S, Sack MN, Greer JJ, et al. Nitrite augments tolerance to ischemia/reperfusion injury via the modulation of mitochondrial electron transfer. J Exp Med 2007; 204: 2089-2012. https://doi. org/10.1084/jem.20070198

50. Shiva S, Gladwin MT. Nitrite mediates cytoprotection after ischemia/reperfusion by modulating mitochondrial function. Basic Res Cardiol 2009; 104: 113-119. https://doi.org/10.1007/s00395009-0009-3

51. Halestrap AP, Richardson AP. The mitochondrial permeability transition: A current perspective on its identity and role in ischaemia/ reperfusion injury. J Mol Cell Cardiol 2015; 78: 129-141. https://doi. org/10.1016/j.yjmcc.2014.08.018

52. Javadov S, Kuznetsov A. Mitochondrial permeability transition and cell death: the role of cyclophilin D. Front Physiol 2013; 4: Article76. https://doi.org/10.3389/fphys.2013.00076

53. Nguyen TT, Stevens MV, Kohr MJ, et al. Cysteine 203 of cyclophilin $\mathrm{D}$ is critical for cyclophilin $\mathrm{D}$ activation of the mitochondrial permeability transition pore. J Biol Chem 2011; 46: 40184-40192. https://doi.org/10.1074/jbc.M111.243469

54. Kohr MJ, Apote AM, Sun J, et al. Characterisation of potential S-nitrosylation sites in the myocardium. Am J Pysiol 2011; 300: H1327-H1335. https://doi.org/10.1152/ajpheart.00997.2010

55. Sun J, Steenbergen C, Murphy E. S-nitrosylation: NO-related redox signalling to protect against oxidative stress. Antioxid Redox Signal 2006; 8: 1693-1705. https://doi.org/10.1089/ars.2006.8.1693 56. Lengyel $\mathrm{C}$, Varró $\mathrm{A}$, Tábori $\mathrm{K}$ et al. Combined pharmacological block of $I_{k r}$ and $I_{k s}$ increases short-term QT interval variability and provokes torsades de pointes. Br J Pharmacol 2007; 151: 941-951. 